Original article

\title{
CHARACTERISTICS OF BUILDING MATERIALS EXPOSED TO GEOENVIRONMENTAL IMPACTS IN MAKAAD RADWAN, OTTOMAN CAIRO, EGYPT ${ }^{(a)}$
}

\author{
Ali, M. ${ }^{1}$, Alenbaawy, M. ${ }^{2} \&$ Moussa, A. ${ }^{1}$ \\ ${ }^{1}$ Conservation dep., Faculty of Archaeology, Cairo Univ., Egypt, ${ }^{2}$ Geology Dep., Faculty of Science \\ Cairo Univ., Egypt-e-mail:dr_abubakr@msn.com
}

\begin{abstract}
The Makaad Radwan monument is situated in the neighborhood of Bab Ziweila in historical Cairo. It was built in the early XVII century (1650 AD). The building is affected by severe deterioration phenomena and patterns of damage which occurred during the time. These deterioration and damages are mainly due to foundation problems, subsoil water and also to the earthquake that affected the whole of Greater Cairo in October 1992. Chemical composition, physical and petrographic properties of the building materials at Makaad Radwan including masonry, stone, mortars, decorated elements and other constituents of the monument were studied to identify their characteristics. Evaluation of the site characteristics and foundation soil condition including description of the soil texture and composition as will as the possible sources .The impacts of the foundation condition are discussed (e.g. karstrficaion and salinization).
\end{abstract}

Keywords: Mekaad Radwan, Chemical Composition, XRD, Physical Properties; Petrography.

\section{Introduction}

Makaad Radwan, fig. (1) is one of the civil architectural buildings that were founded by the ottoman pasha Radwan AlFaqary who used to be the governor of $A l$ Mansoura governorate in the ottoman period of Egypt. It has been built in $17^{\text {th }}$ century (1635 AD). The building is located in old Cairo front of Bab Zweilah (Zweilah gate) and behind Souq El Khayameya, fig. (2). The monument is a part of a complex known as Radwan Palace or Qasabet Radwan which carries number 406 in the Egyptian classification of Islamic and Coptic monuments, while Makaad Radwan carries number 208 which is a separate number apart from the main monument [1]. The references available on the place and surrounding territory don't provide sufficient data to trace a historical sequence up to the present time. The all known data reveals to a high position of Radwan Pasha during the ottoman era, no written resources are available on that topic. The local data taken from the residences surround the monument mention that there was a high destruction after the 1992 earthquake in its walls and ceiling. Restoration efforts were achieved by a local construction company, but the optical investigation of these previous activities has detected many mistakes in the techniques and the materials used, for example Portland cement was used as a plastering material and a main grout for injecting the faults. 


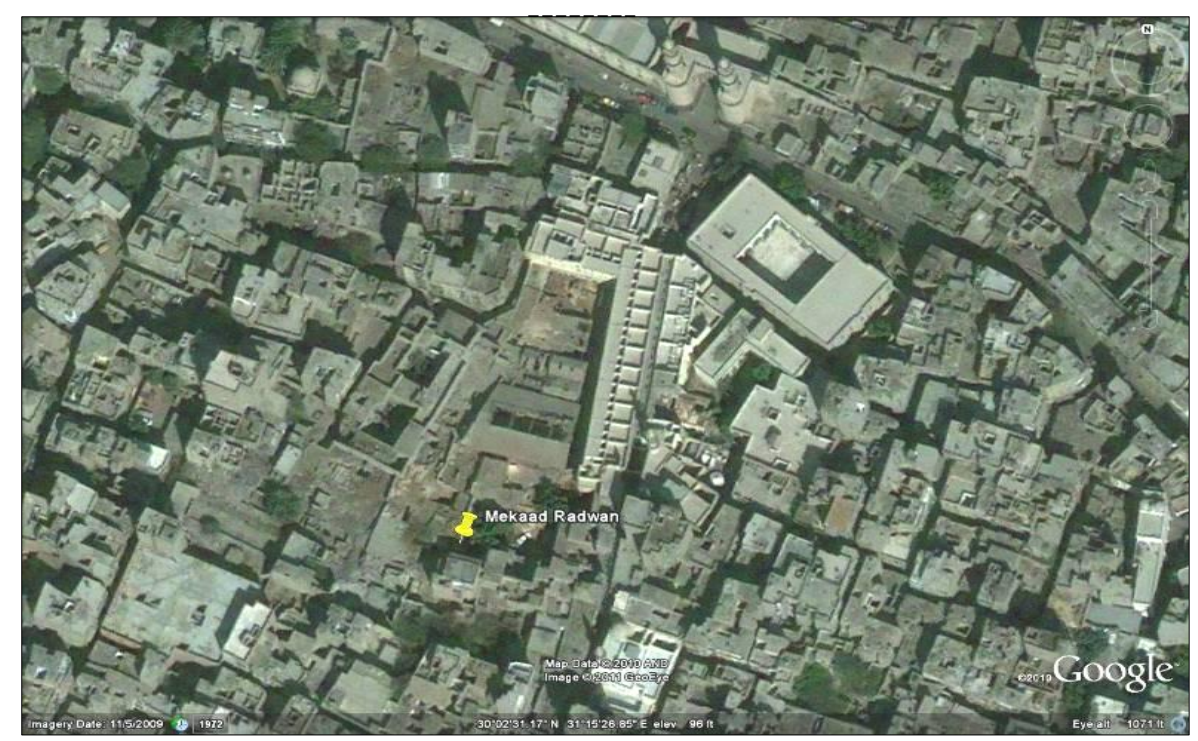

Figure (1) the location of Makaad Radwan (Google earth)
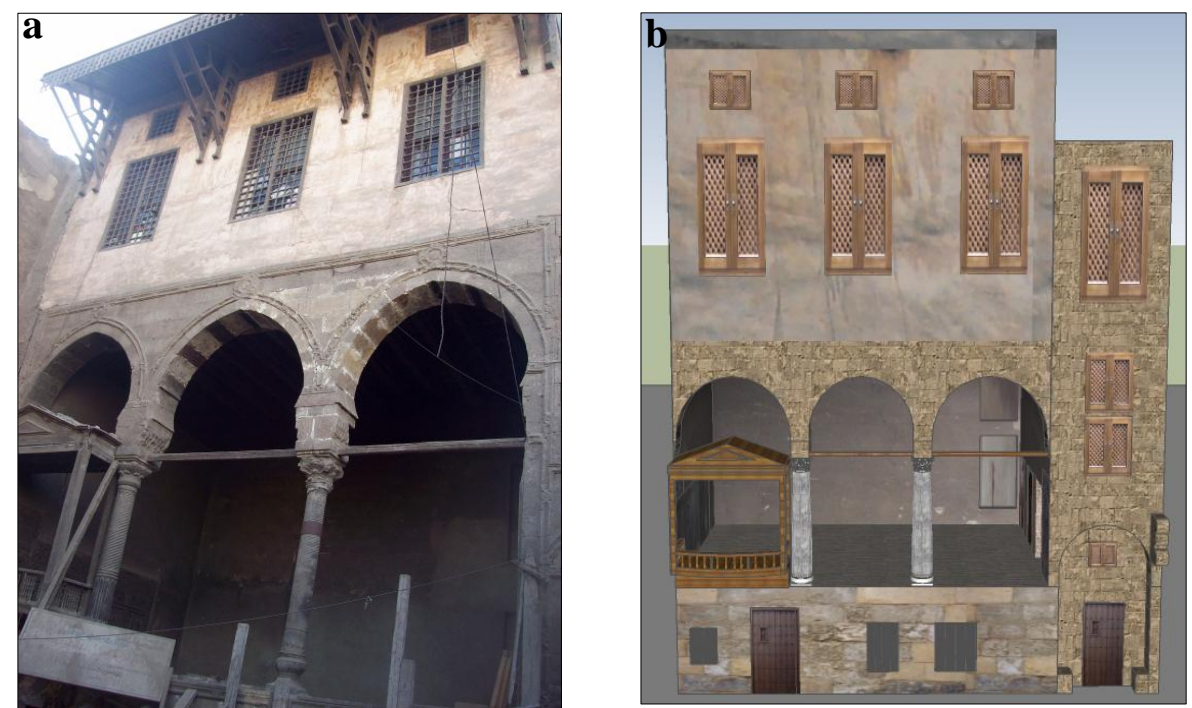

Figure (2) $\underline{\mathbf{a}}$ the Makaad Radwan, $\underline{\mathbf{b}}$ The Makaad Radwan façade (AutoCAD)

The present study aims essentially to determine which numerous causative factors play roles of damages and deterioration situation in each element of the masonry and to which level of safety. The study also make it possible to know the real response of the masonry structure to the deformation imposed at the base of the foundation condition or/ and at base of other causative factors, such as seismicity situation. This may be very useful; both in correctly analyzing the development of damage picture and in rational definition of the restoration work necessary. By this way the results of the present study may be extrapolated to be used in similar Islamic building that suffering from same problems. The present study emphasized on the following objective: - Description of the site location, historical importance and architectural elements of the Mekaad Radwan as case study for Ottoman Islamic monument. - Identification of the characteristics of the primary building materials including masonry, stone, mortars, decorated elements and other constituents of the monument. Evaluation of the site characteristics and foundation soil condition including description of the soil texture and composition as will as the possible sources .The impacts of the foundation condition are discussed (e.g karstrficaion and salinization). 


\section{Technical steps and laboratory analyses}

To achieve the aim and objectives of the study the following technical steps were carried out. $1^{\text {st }}$ step Collection and registration of the historical documents of the monument site as well as the previous related geological and archaeological studies. $\underline{2}^{\text {nd }}$ step Field investigation including description of the site elements, geognostic measurements analysis .Collection of the study samples including representative pieces of building stone, tiles, red bricks, decorative elements and mortars, as well as some samples from the foundation soil with subsoil water was also carried out. $3^{\text {rd }}$ step Laboratory analysis including physical, mineralogical petrographic and geotechnical analysis of collected samples. $4^{\text {th }}$ step Presentation data processing and interpretation of the results and photograph obtained and written the technical report. The collected materials (rock, mortar and soil samples) from different building elements were described, mechanically and geotechnically analyzed. The mechanical analysis of the foundation of soil mater and microscopic investigation were carried out in the Geology department, Cairo University, while their mineralogical

\section{Results}

\subsection{Masonry Stone}

All the stone blocks of building are of limestone. This limestone belongs to the Mokattam formation of Middle Eocene age. The building blocks and tiles are hard chalky limestone with microfossils e.g. Nummulite or /and Alveolina tests. In this respect they are very similar or identical to most of the Middle Eocene Mokattam quarries that located around the old Cairo

\subsubsection{Petrographic investigation}

The results of the microscopic investigation of limestone samples are shown in figures 3 to figure 12 inclusive and their XRD analysis are shown in figures 13 and 14. Petrographically, three types of limestone were identified within the architectural elements. The first rock

city. The masonry stones are suffering from cracking and micro fissures [2][3]through which salinization and chemical weathering taking place due to natural digenetic factures and microporosity or to the effects of surface karstification that represented by cavities and salinization.

type (Foraminiferal lime-mudstone to wacked-stone), fig $(3 \& 4)$. The most common type consisting the limestone blocks of the internal western and eastern walls of the Makaad Radwaan meetings room and is represented by sample (LSC). The second type (Dolomitic skeletal 
packstone), fig s $_{\text {( }}$ \& 6 ), is very common in facades of the ground floor and the site gate of the building and is represented by sample (RLS). The third type (Skeletal
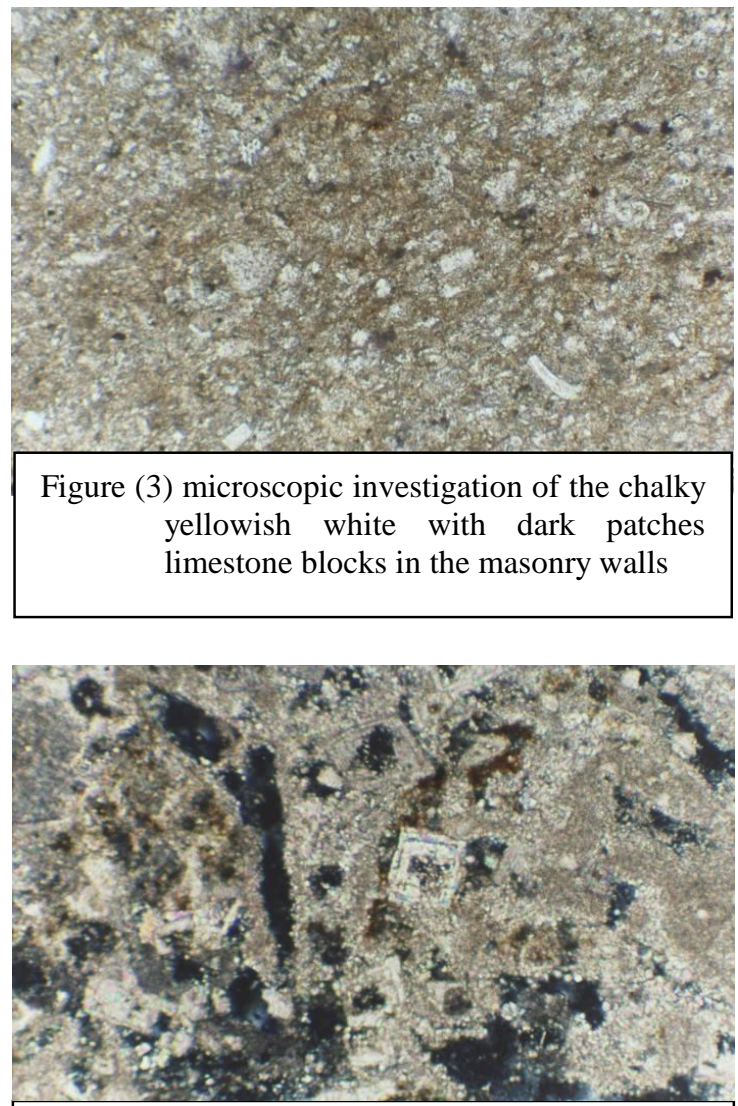

Figure (5) the shell fragments imbedded in dolomitic micrite which partially recrystallized into microsparry calcite $\left(2^{\text {nd }}\right.$ limestone type)

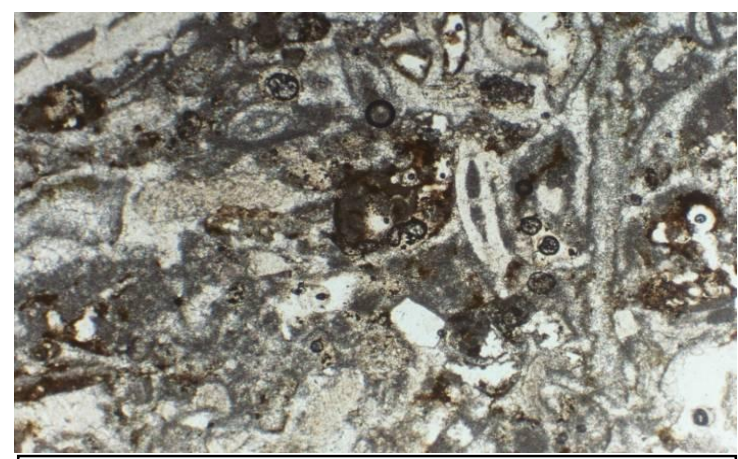

Figure (7) the chambers of some tests are filled with sparry calcite (third limestone type)

\subsubsection{Foraminiferal Lime-Mudstone to Wakestone}

This type represents the chalky yellowish white with dark patches limestone blocks in the masonry walls. It
Packstone to Grainstone), figs (7 \& 8), common in the ground tile of the Makaad Radwaan meetings room.

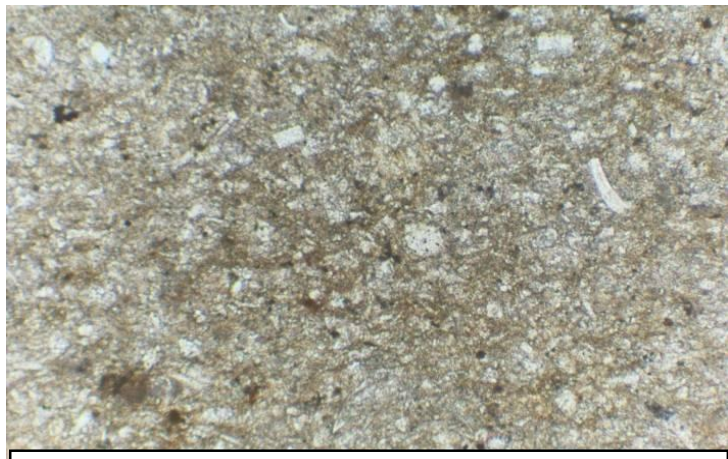

Figure (4) micro-porosity with numerous dissolute pores and microcainties in the first limestone type at Makaad Radwan

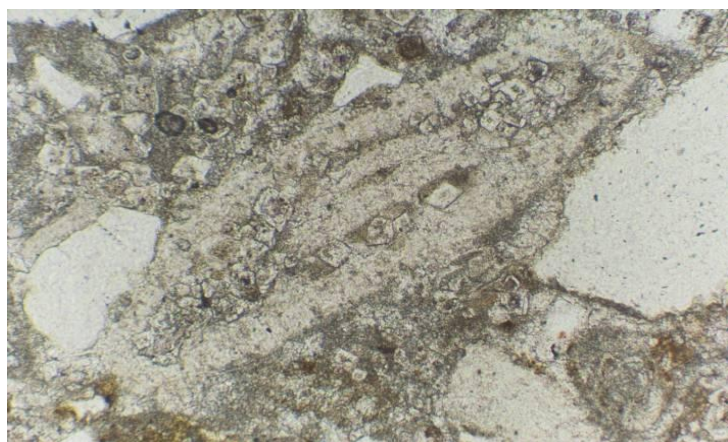

Figure (6) some voids are shown with partially filling of zoned idiotopic ferron dolomite or ankerite rhombs (second limestone type)

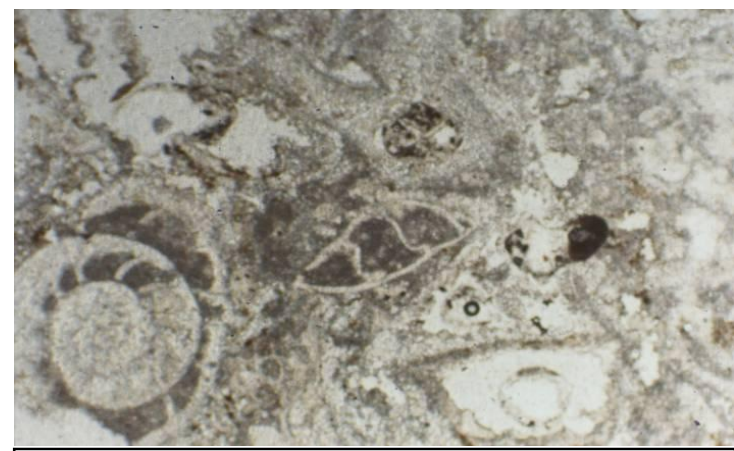

Figure (8) isopachous calcite crystals exist on the boundary of some bivalve shell fragments (third limestone type)

ranges from foraminiferal limemudstone to wakestone showing microporosity with numerous dissolute 
pores and microcainties. The skeletal particles are mainly represented by benthonic and minor planktonic foraminiferal tests in addition to some algal fragments. These particles are randomly scattered within microcrystalline lime mud matrix. Very few fine quartz grains, traces of gypsum particles and dolomite rhombs could be observed in some parts of the rock. The result of the XRD analysis, fig (9), supports the mineral composition of the rock that revealed from the thin section investigation, as listed in tab. (1).

Table (1) the identification minerals and their relative abundance in the limestone blocks of Makaad Radwaan

\begin{tabular}{|c|c|c|c|c|c|c|}
\hline \multirow[b]{2}{*}{ Rock type } & \multirow[b]{2}{*}{ Symbol } & \multicolumn{5}{|c|}{ Relative abundance of the minerals } \\
\hline & & Calcite & $\begin{array}{l}\text { Fe. dolomite } \\
\text { Ankerite }\end{array}$ & Gypsum & Quartz & Halite \\
\hline $\begin{array}{l}\text { Foraminiferal Lime- } \\
\text { mudstone to Wakestone }\end{array}$ & LSC & $88 \%$ & $2 \%$ & $49 \%$ & $6 \%$ & - \\
\hline Dolomitic Packstone & RLS & $68 \%$ & $21 \%$ & $2 \%$ & $7 \%$ & $2 \%$ \\
\hline
\end{tabular}

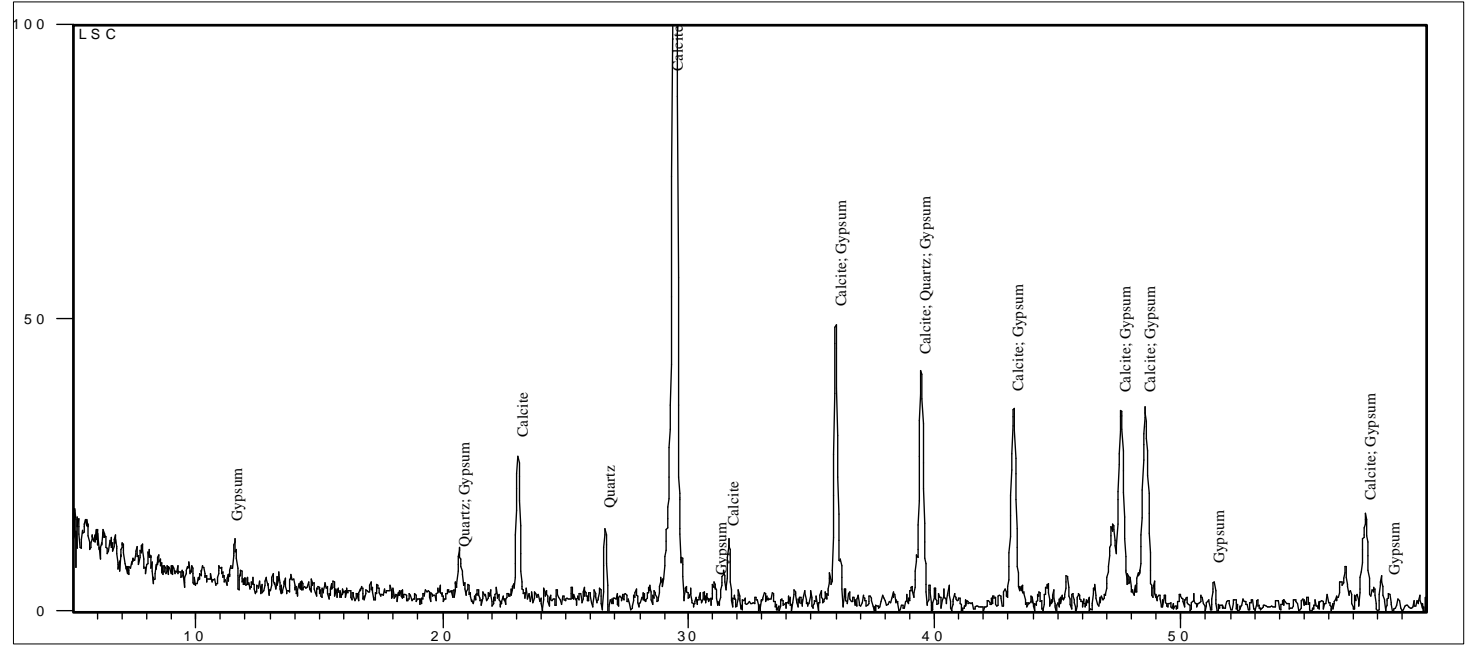

Figure (9) XRD analysis pattern of the yellowish limestone at Makaad Radwan

\subsubsection{Dolomitic skeletal packstone}

This rock type is characterizes by reddish color with clear dark patches composed of foraminiferal tests, algal fragments and pelecyponda shell fragments imbedded in dolomitic micrite which partially recrystallized into microsparry calcite. The rock has numerous pores, shrinkage microcracks and microvoids. Some voids are shown with partially filling of zoned idiotopic ferron dolomite or ankerite rhombs. Some other rhombs are scattered in a reddish lime mud matrix. The ankerite rhombs have dark core of iron oxide and clear outer rims. The chambers of the foraminferal tests are filled with sparry calcite and their walls are heavily micritized. The pelecypod shell fragments are originally preserved in its fibrous texture, although some parts of them are partially recrystallized to sparry calcite, some concave-convex grain mechanical compaction. In this rock dolomitization and neamorphism are the most digenetic features. The pare spaces observed in the reddish dolomitic parts of the rock, may be due to the dissolution of the carbonate crystals as later stage of diagnosis. The mineralogical composition as interpreted from the XRD analysis, Fig. (10), proved that the rock is essentially composed of calcite $(68 \%)$ followed by ankerite $(21 \%)$ with traces of quartz $(7 \%)$, gypsum $(2 \%)$ and halite $(2 \%)$. 


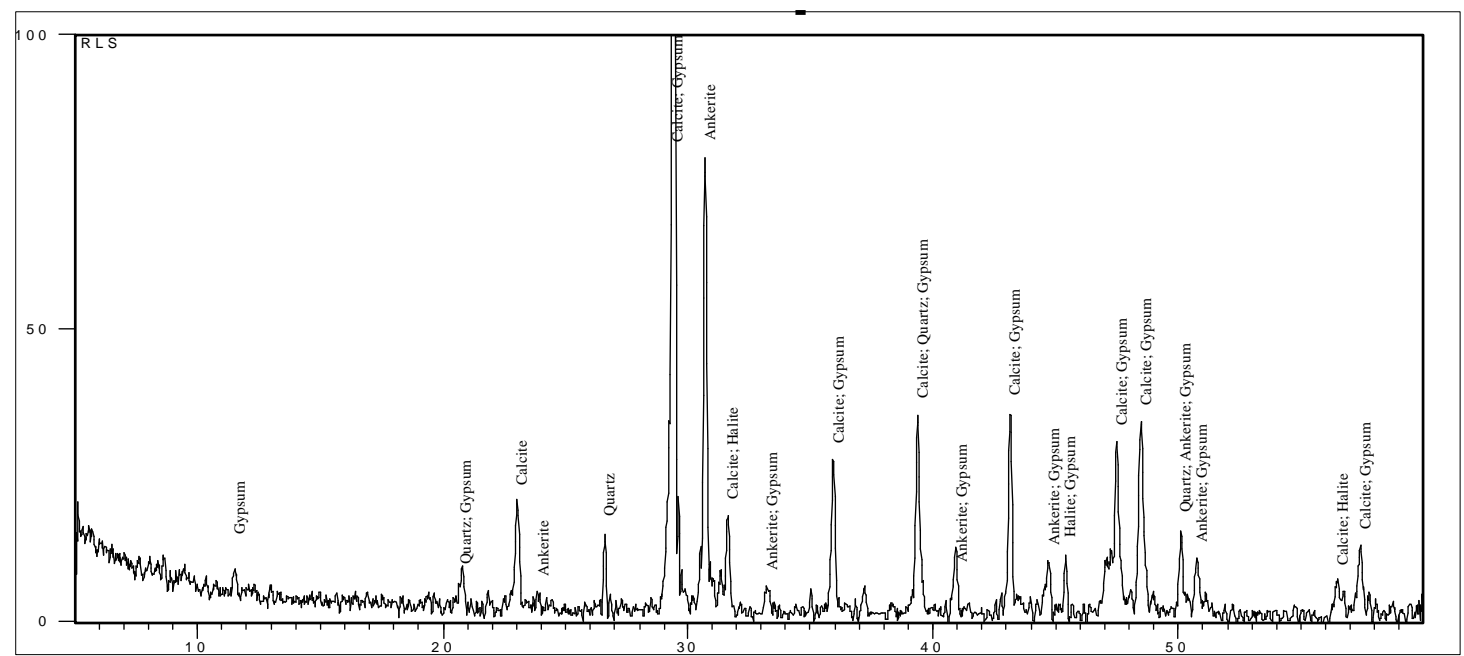

Figure (10) XRD analysis pattern of the reddish limestone at Makaad Radwan

\subsubsection{Skeletal packstone to grainstone}

This highly fossiferous limestone is very common in tiles used at the ground of Makaad Radwan room. It is mainly made up of skeletal particles, bioclasts (e.g. shell fragments of pelecypod and occasionally gastropod as well as large foraminiferal test) cemented by microsparite or embedded in lime mud matrix. Some of the bioclasts are rimmed

\subsection{Mortars and Plasters}

Mortar and plaster are of the most effected building and decorated materials by deterioration factors. The analysis of mortar and plaster samples is an important step before any restoration works. So, the samples must be prepared carefully for physical, mineralogical and petrographic analysis. In the present case study several samples were collected from ancient and recent mortars as well as from recent by micrite envelopes and their cavities are filled with errant sparry calcite while others are partially or completely micritized. The chambers of some tests are filled with sparry calcite while wall still preserved without aggregating neamorphism. Isopachous calcite crystals exist on the boundary of some bivalve shell fragments.

plasters that were used during the last restoration upon either limestone blocks or the red bricks. However, some physical properties couldn't be evaluated due to the deterioration cycles that toke place for many decades and affected badly these properties. Table (2) illustrate the specific locations of the mortar and plaster samples within the different elements of the study monument Makaad Radwan.

Table 2: the studied specific location

\begin{tabular}{|c|c|c|l|l|} 
Samples Type & Sample No. & Symbol & & \multicolumn{1}{c|}{ Specific location } \\
\hline \multirow{3}{*}{ Mortar } & 1 & MBM & Binding mortar between red bricks \\
& 2 & LSM & Binding mortar between limestone blocks \\
\hline \multirow{3}{*}{ Plaster } & 3 & ZLSP & Binding mortar between zigzag limestone blocks \\
\hline & 5 & MME & Collating mortar of the mosaics \\
\hline & 6 & MBP & Plaster upon the red brick \\
\hline
\end{tabular}

\subsubsection{Petrographic investigation}

The petrographic investigation proved that the (LSP) plaster sample located upon the limestone blocks is similar to the mortar sample that binding the same blocks. Both are composed of lime lumps represented by fine calcite 
particles with gypsum, few anhydrite crystals, and few fine quartz sand grains, fig (11), some additives (very fine fibrous and organic materials) are also observed embedded in the gypsiferous lime matrix. Some gypsum particles seem to be altered to anhydrite crystals. The XRD results support the composition of this sample.

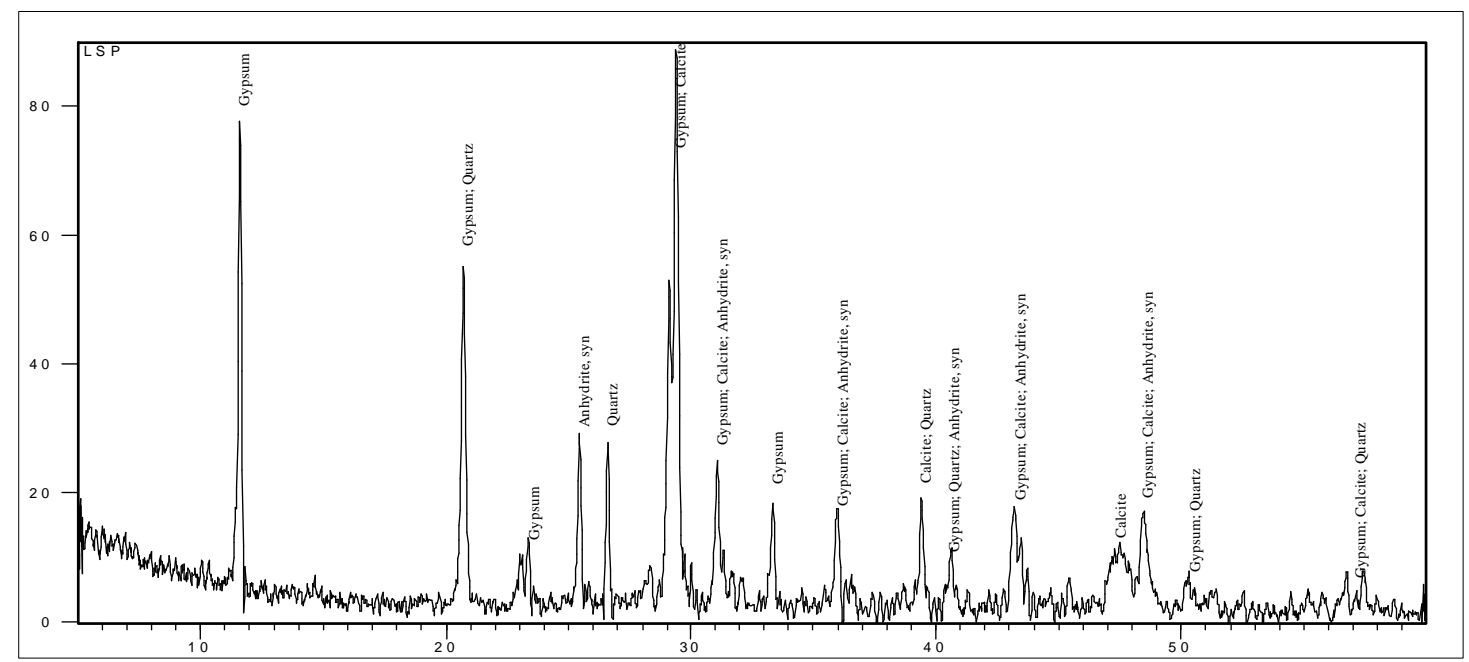

Fig. 11: XRD analysis pattern of the plaster upon the limestone at Makaad Radwan

In addition the XRD result of the samples indicated that there are three types of mortar, the first is lime mortar, sample MBM which used as binding material between the red bricks, the second one is lime-gypsum mortar respective stone blocks sample LSM, and the third type is gypsum mortar used as binder sample ZLSP which was used as binding of the zigzag decoration elements and mosaics, and sample MME which was derived from the mortar collating the mosaic tiles into the walls. The first type, fig. (12), mainly consists of calcite (68\%) and gypsum (7\%) with quartz $(25 \%)$. The second type, fig. (13), contains gypsum (24\%), calcite (32\%) with excess quartz (35\%) in addition to some feldspar grains (9\%). Such feldspar (mainly k-feldspar) associated with a part of quartz may be derived from granitic rock powder which

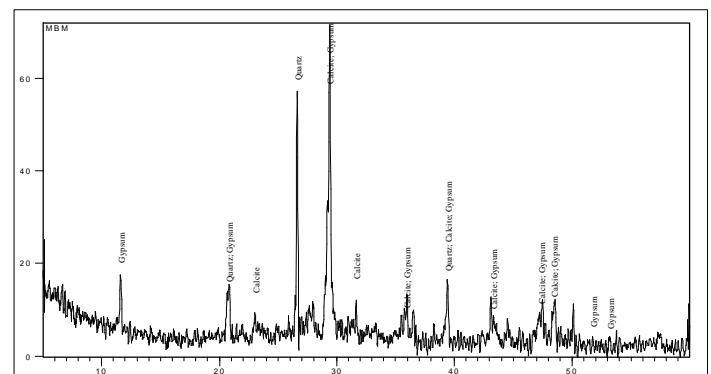

Figure (12) XRD analysis pattern of the binding mortar between red bricks possibly was added as additives to ancient mortar. The third type, fig. (14), consists of gypsum (72-76\%), little calcite (11$12 \%)$ and traces of quartz $(5-6 \%)$. The weathered gypsum mortar usually includes $8-10 \%$ (sodium chloride) which is called in the X-ray chart "synthetic halite". It was formed from salinization weathering processes affecting mortar layers. That salt has a negative influence on the quality of the mortar, fig. (15). The plaster samples are lime-gypsum type. The X-ray analysis of the plaster samples (MBP) and (LSP) shows that they are composed of (45-51\%) calcite (lime), (39-44\%) gypsum and traces of quartz (5-8\%), fig. (16). Some ancient mortar or plaster, such as sample (LSP) occasionally contains few anhydrite crystals (8\%) that may be formed by dehydration of the original gypsum at higher temperature, fig. (17).

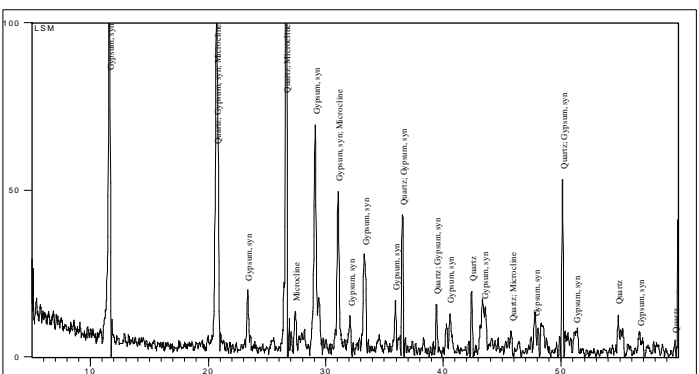

Figure (13) XRD analysis pattern of the binding mortar between limestone blocks 


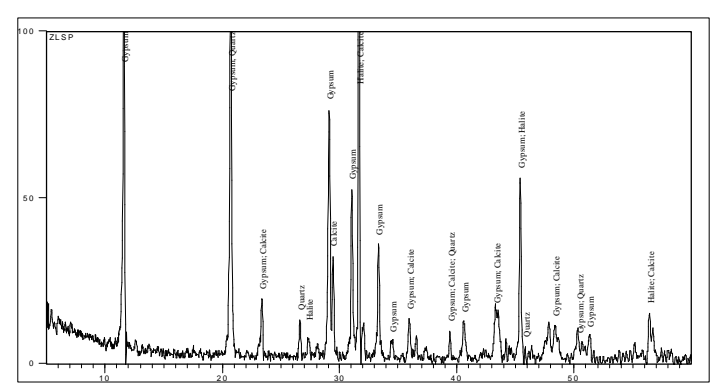

Figure (14) XRD analysis pattern of the binding mortar between zigzag limestone blocks

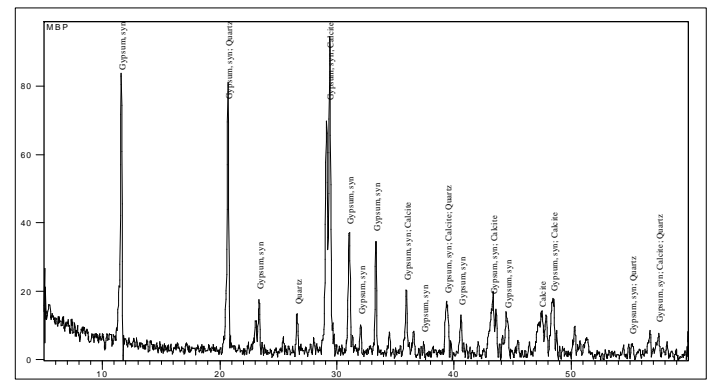

Figure (16) XRD analysis pattern of the plaster upon the red brick at Makaad Radwan

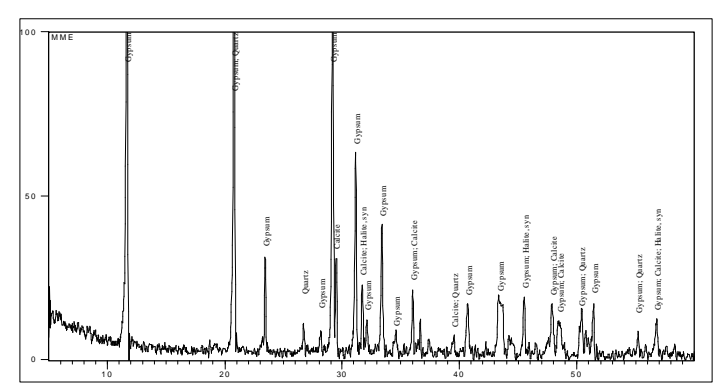

Figure (15) XRD analysis pattern of the mortar collating mosaics into the walls

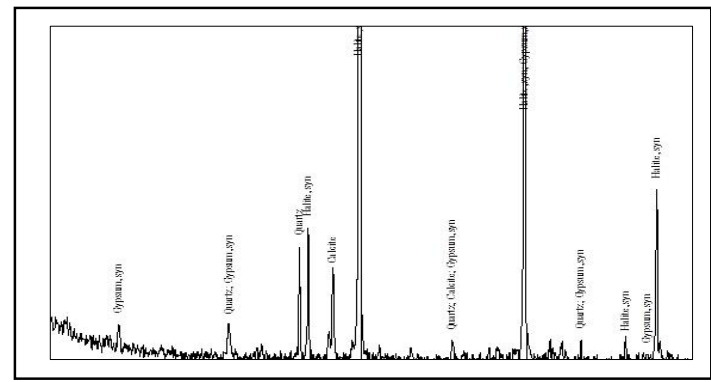

Figure (17) XRD analysis pattern of a salt sample upon the limestone blocks at Makaad Radwan

\section{Subsoil water and Geo-environmental impact}

The subsoil water level is very high and can be observed within surface soil of foundation inside the workshop room in the ground floor of the Makaad Radwan building. Old Cairo is suffering from the rising of the water table that has affected the whole urban and historical areas during the last decade [4], due to different reasons of which: *The hectic growth of population and leakage of the domestic water and sewage system. *The possible infiltration of the excess drainage water coming from the nearly green areas (e.g. gardens). *The possible lateral and upward seepage of water from the shallow angrier and River Nile. * The impervious concrete barriers and tunnels of underground metro that currently carrying out may prevent the natural flowing of groundwater and subsequently tending to excessive rise in subsoil water. *The possible leakage of water that may be coming from the limited (local) industrialization which is adding environmental decay cause. The Mekaad Radwan site is suffering from not only salt weathering but also from some disturbance of external works and human activities. The external work (e.g. misuses of historical building nearby constructions) and human activity (e.g. workshops and other commercial activities). All of these activities by time may be cause slowly and significant alterations such as the stresses pattern in the structural elements of building. The following is brief account on the impacts of moisture, humidity, salt weathering and foundation condition as well as the human induced activities as illustrated from some examples of dramatically deteriorated architecture elements. *External pulverization, swelling, blocks siding falling and collapsing of walls ceiling, ground of the workshop site at the ground floor of the building. *Cracking missing of plaster layer, Salinized spots and efflorescence. Salt crystal aggregates scattering on red brick, mortar, mosaic, ground tile, column's base. *Deformations imposed on the foundation as a result of soil 
subsidence which may cause lesions or aggravation of an exiting pattern of cracks, according to the stresses induced in the bearing elements. *Deterioration (karstification, exfoliation erosion, corrosion) at the basis of the walls due to

\section{Discussion}

Through the previous study, it could be affirm that the determination of the different components proportion and the study of their deterioration and damage situation is very important before any restoration efforts. Some samples have a few content of sodium chloride which has negative influence on the quality of the mortar. Most of the investigated samples contain both gypsum as well as calcite in the form of limestone powder. Climatic conditions with high moisture levels are usually the important causative factors for the deterioration and mortar-plaster loss [5]. However the interior composition particularly the proportion of gypsum and sand additives of the mortars is another significant factor controlling the level of cracking and losses [6]. Generally in preparation of mortar or plaster for restoration processes, the addition of gypsum improves the strength of limevarious pozzolan mixes, but the gypsum content should remain limited because the ettringite formation causes swelling and disintegration of the material [7] [8]. Sometimes, it is recommended to use lime/sand mortar, like that of sample (MBM) because it is more appropriate for repair of old masonry with an existing lime mortar, and where exposure to climate loads is low. It is important to avoid the presence of soluble salts, or salt crystals in the prepared mortar for restoration and therefore avoiding efflorescence and sub-efflorescence appearances. These properties can be relatively modified by altering the process of production of the mortar, the type of aggregate, the aggregate/binder and water/binder ratio....,etc. [9]. The degradation process that affecting nearly all Egyptian monuments is caused mainly the rising of dampness by capillary suction from the subsoil water. * Missing of decoration features, discoloration, pitting, scaling and exfoliation the wooden ceiling of the balcony.

by the crystallization of various salts [10]. Significant parts of building stones, bricks, mortar and plasters of the Makaad Radwan building were suffered from saltweathering and salinization process. These processes are caused by the crystallization of various salts, mainly sodium chloride beneath the surface layers of the masonry. Occasionally under certain physical conditions these salt crystals are brought to the surface of the stone. A number of factors influence salt crystallization damage in porous materials, including pore size and porosity; the nature of the salt, the ease with which it achieves high saturations by evaporation and/or variations in environmental temperature and, the energy difference between the crystal and the pore wall; the transport of the solution, in terms of the supply rate of the solution and the evaporation of water and strength, which is the material's resistance to crystallization pressure [11] [12]. To confirm the identification of the result, X-ray analysis was carried out on a salt sample shown in fig. (17). XRD result indicate the dominance of sodium chloride crystals (halite synthetic) with about $74 \%$ with some contamination of accessory material like quartz as sand $12 \%$, calcite (as lime powder) and synthetic gypsum. Such contaminants may be derived from the mortar or plaster used in this wall. Based on the previous studies concerning the salt weathering process, the data analysis has essentially shown two kinds of action by the moisture. $1^{\text {st }}$ one, is the absorption of humidity from the air by the salts inside the walls and. $\underline{2}^{\text {nd }}$ one, is the rising moisture from the ground water or subsoil water. In the present study the sources of salts inside the walls are mainly coming from natural or synthetic salts 
included in the limestone blocks, the red brick as well as in mortar or plaster. The source of rising moisture is coming from the sub-soil water at the foundation level.
The availability of this condition may increase the quantity and dampness height within the ground floor of the study monument.

\section{Conclusion}

Based on the results of the XRD analyses and the microscopic investigation of the studied building materials from Makaad Radwan, it has been concluded that the masonry stone is a hard chalky limestone, which belongs to the Mokattam formation of Middle Eocene age and composes mainly of calcite. Petrographically, three types of limestone were identified within the architectural elements: the first is foraminiferal lime-mudstone to wacked-stone, the second is dolomitic skeletal packstone, and the third is skeletal packstone to grainstone. The $X R D$ result of mortars indicated that there are three types: - the first consists of calcite (68\%) and gypsum (7\%) with quartz (25\%), the second contains gypsum (24\%), calcite (32\%) with excess quartz (35\%) in addition to some feldspar grains (9\%), the third type consists of gypsum (72-76\%), little calcite (11-12\%) and traces of quartz (5-6\%), while plaster samples are lime-gypsum type composed of (45-51\%) calcite (lime), (39-44\%) gypsum and traces of quartz (5-8\%). Geoenvironmental factors including subsoil water and soluble salts are the dominant effective deterioration agents at the case study; subsoil water level is very high and can be observed within, surface soil of foundation, while some samples have a certain content of sodium chloride which has negative influence on the quality of the mortars.

\section{Endnotes}

(a) This research is a part of NIKER PROJECT $N^{\circ}: 244123$ FP7 (NEW INTEGRATED KNOWLEDGE BASED APPROACHES TO THE PROTECTION OF CULTURAL HERITAGE FROM EARTHQUAKE-INDUCED RISK

\section{References}

[1] Jaint Committee on Powder Diffraction Standards "JCPDS", (1967)., index to the powder diffraction file, American society for testing and materials, Pennsylvania.

[2] Said, R., (1981). The Geological Evolution of the River Nile, I-VIII, Springer-Verlag, Heidelberg, Germany.

[3] Said, R., (1990), The Geology of Egypt, Balkema, Rotterdam, Netherlands.

[4] Fitzner, B., Heinrichs, K. \& La Bouchardiere, D., (2002 ${ }_{\mathrm{a}}$ ). Limestone weathering of historical monuments in Cairo, Egypt, in: Natural stone, weathering phenomena, conservation strategies and case studies, Siegesmund, S., Weiss, T. \& Vollbrecht, A., (Eds.), Geological Society, London, Special Publication, 205, The Geological Society of London, United Kingdom, pp: 217-239.

[5] Zehnder, K., (2007). Long-Term Monitoring of Wall Paintings
Affected by Soluble Salts, Journal of Environmental Geology, Vol. 52, pp: 353-367.

[6] Wüst, R. \& Schlüchter, Ch., (2000). The origin of soluble salts in rocks of the Thebes mountains, Egypt: The damage potential to ancient Egyptian wall art, Journal of Archaeological Science, Vol. 27 (12), pp: 1161-1172.

[7] Toumbakari, E., (2002). LimePozzolan-cement grouts and their structural effects on composite masonry walls, (Ph.D.), Katholieke Universiteit, Belgium.

[8] Maurenbrecher, A., (2004). Mortars for repair of traditional masonry, in: The ASCE practice periodical on structural design and construction, Ottawa, Canada.

[9] Palomo, A., Blanco-Varela, M., Martinez-Ramirez, S., Puertas, F., \& Fortes, C., (2004), Historic mortars: characterization and durability, New Tendencies for research, Advanced research centre of cultural heritage interdisciplinary projects, $\quad 5^{\text {th }}$ 
framework programme workshop, Mendely, Madrid, Spain.

[10] Fitzner, B., Heinrichs, K., La Bouchardiere, D., (2002b), Damage index for stone monuments, in protection and conservation of the cultural heritage of the Mediterranean cities, in: Galan, E. \& Zezza, F., (Eds.), Proceedings of the 5th International symposium on the conservation of monuments in the Mediterranean basin, Sevilla, Spain, 2000, Galan, E. \& Zezza, F., (Eds.), Swets \& Zeitlinger, Lisse, Netherlands, pp. 315-326.
[11] Benavente, D., Cueto, N., MartinezMartinez, J., del Cura, M. \& Canaveras, J., (2007). The influence of petrophysical properties on the salt weathering of Porous Building, Rocks, Environmental Geology, Vol. 52, pp: 215-224.

[12] Moussa, A., Kantiranis, N., Voudouris, K., Stratis, J., Ali, M., \& Christaras, B., (2009), Impact of soluble salts on the deterioration of Pharaonic and Coptic wall paintings in Al Qurna, Egypt: Mineralogy and Chemistry, Archaeometry, Vol. 51 (2), pp: 292-308. 